\title{
Sınır Ötesi Şirket Satın Alma İşlemlerine Genel Bakış: 1998 - 2018 Dönemi Türk Şirketleri Üzerine Bir İnceleme*
}

\author{
An Overview of Cross-Border Acquisitions: A Study on Turkish Companies in the Period 1998-2018
}

\author{
Sibel AYAS \\ Dr., Independent Researcher, \\ ayassibel@gmail.com \\ https://orcid.org/0000-0002-0806-1700
}

Makale Başvuru Tarihi: 26.05.2020

Makale Kabul Tarihi: 30.08.2020

Makale Türü: Araştırma Makalesi

Anahtar
Kelimeler:
Sinır Ötesi Şirket
Satın Alma,
Yabancı Doğrudan
Yatırım,
Türkiye,

Keywords:

Cross-Border Acquisitions,

Foreign Direct Investment,

Turkey,

\section{ÖZET}

Sinır ötesi gerçekleştirilen şirket satın alma faaliyetleri tüm dünyada olduğu gibi Türk şirketlerinin de ilgisini çekmektedir. Bu çalışmanın amacı ise, hedef ya da alıcı şirketlerden birinin Türk diğerinin yabancı olduğu satın alma faaliyetlerini incelemek ve genel bir çerçeve sunmaktır. Bu çalışmada kullanılan veriler Zephyr isimli veri tabanından elde edilmiştir. 1998-2018 yılları arası yirmi yıllık dönem içerisinde gerçekleştirilen Türklerin yurt dışında yaptığı 275 işlem ile yabancı firmaların Türkiye'de gerçekleştirdiği 883 satın alma işlemi araştırmanın kapsamını oluşturmuştur. Yapılan analizlerin sonucu satın alma işlemlerinin genellikle Avrupalı firmalarla gerçekleştirildiğini göstermiş̧tir. İşlem sayısı ve işlem hacmi yıllar itibariyle değiş̧kenlik göstermektedir. En fazla satın alma faaliyetinin gerçekleştirildiği sektörler finans ve imalat sektörleri olarak dikkat çekmektedir. Genel olarak yatay olmayan satın alma işlemlerinin yatay satın alma işlemlerine göre daha fazla sayıda olduğu görülmüştür.

Bu çalışmada kullanılan veriler, SOAS University of London'da doktora sonrası yapılan çalışmalar esnasında elde edilmiştir. 


\section{GIRISS}

Birçok şirket büyümek, değişen çevreye ayak uydurmak ve yabancı bir pazara daha hızlı girebilmek için uluslararası (sınır-ötesi) şirket birleşme ve satın alma faaliyetlerinde bulunur. Geçmiş yıllarda, tüm dünyada gerçekleştirilen uluslararası şirket satın alma faaliyetlerinin büyük çoğunluğu gelişmiş ülke şirketleri tarafindan gerçekleştirilmektedir. Buna karşın, son yıllarda özellikle Çinli ve Hindistanlı şirketlerin uluslararasılaşma stratejisi olarak farklı ülkelerde şirket satın alma yoluna gitmesi global düzeyde birçok araştırmacının dikkatini çekmektedir (Bhagata vd., 2011:251). Dünya Yatırım Raporu'nda (2018) görüldügü üzere Türkiye gibi gelişmekte olan ülkeler, hem satın alma sayısı hem de satın alma büyüklügü açısından yatırımcıların dikkatini çekmektedir. Sınır-ötesi şirket satın alma ve birleşmelerinin tüm dünyada bu kadar ilgi çekmesinin çeşitli nedenleri olabilir. Küreselleşme, özelleştirme, liberalleşen ekonomiler ve teknolojik gelişmeler ve farklı bölgelerde ve pazarlarda yeni firsatlar yaratma ihtiyacı şirketleri birleşme ve satın almaya iten önemli unsurlar olarak kabul edilmektedir (Shimizu vd., 2004:308).

Sınır-ötesi şirket satın alma faaliyetlerinde taraflardan birinin gelişmekte olan ülkelerde yer alan firmalardan oluşması alan yazınında da ilgi çekmektedir. Ancak Türkiye bağlamında yapılan çalışmaların sınırlı olduğu görülmektedir. Hem hedef ülke olarak hem de alıcı ülke olarak Türk şirketlerin yer aldığı çalışmalar görece oldukça azdır (Genç ve Kalkan, 2018:791; Yıldırım, 2017:276). Dolayısıyla Türkiye bağlamında yapılan çalışmaların alan yazınında eksikliği görülmektedir. Bu çalışmanın amacı ise 1998-2018 yılları arasında gerçekleşen Türk şirketlerin yer aldığı uluslararası şirket satın alma işlemlerini incelemek ve çok yönlü bir bakış açısı sunmaktır. Spesifik olarak, 20 yıllık dönem içerisinde gerçekleşen taraflardan alıcı şirketin Türk olduğu ya da hedef şirketin Türk olduğu tüm sınır-ötesi şirket satın almalar incelenmiş̧ir. Buna göre bu makalenin önemi, Türk şirketlerinin yatırım yaptığı ülkeler dağılımı, yıllara göre satın alma sayısı, satın alma büyüklüğü, satın alma oranı, satın alma çeşidi, firmaların faaliyet alanları, ve tamamlanma oranı gibi birçok ampirik kanıt sunmasidir.

Her ülkenin kendine has farklı ekonomik, kurumsal ve kültürel yapısı (Hofstede, 1980:13; House vd., 2002:3) vardır. $\mathrm{Bu}$ farklılıkların getirdiği bazı zorluklar olmasına rağmen firmalar bazen yerel satın alma yerine uluslararası satın almayı tercih edebilirler. Dolayısıyla ulusal (domestic) satın almalar ile sınır ötesi (crossborder) satın almaların farklı belirleyicileri olabileceğinden dolayı daha önceki çalışmaların aksine (Genç ve Kalkan, 2018:791), bu çalışma sadece sınır ötesi satın alma işlemlerini kapsamıştır.

\section{SINIR ÖTESİ ŞIRKET SATIN ALMA İŞLEMLERİ}

Şirket satın almaları özellikle yeni bilgilere ve yeteneklere erişim için önemli fırsatlar sunabilir (Shimizu vd., 2004:309). Birleşme ve satın alma davranışlarını etkileyen birçok stratejik neden olabilir. Özellikle sınır-ötesi şirket birleşme ve satın almalarını sadece tek bir nedene bağlamak doğru olmaz. Hem teoride hem de uygulamada firmaları birleşmeye ve satın almaya iten çeşitli faktörler vardır. Daha açık bir ifadeyle, sinerji yaratma, pazar gücünü arttırma, yeteneklere ulaşma, kaynakları genişletme, yabancı pazarlara giriş ve bölgesel çeşitlilik gibi stratejik nedenlerle satın alma ve birleşme yapılabilir (Gaughan, 2015:125; Morresi ve Pezzi, 2014:153).

Şirket birleşme ve satın almalar, stratejik büyüme için uzun yıllardır firmalar tarafından kullanılan önemli bir araçtır. Ancak son yıllarda teknolojik gelişmeler ve küreselleşmenin etkisiyle sınır-ötesi şirket birleşme ve satın almalarının popülerliği hem akademik hem de iş dünyası açısından giderek artmaktadır. Şirket satın almaları sadece ülkenin kendi içinde değil uluslararası bağlamda da oldukça önemlidir. Dünya yatırım raporu (2016:1214) verilerine göre bir ülkeye yapılan yatırımın büyük bir kısmını sınır-ötesi şirket birleşme ve satın alma işlemleri oluşturmaktadır. Örneğin, bu rapora göre 2015 yılında gelişen Asya bölgesi içerisinde değerlendirilen Türkiye en fazla yatırımcı çeken beşinci ülke konumundadır (Dünya Yatırım Raporu, 2016:43). Dünya yatırım raporunun gelecek yıllardaki değerlendirmelerinde ise Türkiye'nin gelişen Asya bölgesinde ilk beşte yer almadığ1 görülmektedir (Dünya Yatırım Raporu, 2017:49; Dünya Yatırım Raporu, 2018:44; Dünya Yatırım Raporu, 2019:40). 


\subsection{Satın Almanın Tanımı, Önemi ve Çeşitleri}

İşletmeler rekabet üstünlüğü sağlamak veya büyümek için birleşme ve satın alma stratejileri uygularlar. En basit ifadeyle; iki şirketin eski kimlik ve tüzel kişiliklerini sona erdirerek, sahip oldukları tüm varlıkları birleştirmek suretiyle genellikle yeni bir isim altında bağımsız yeni bir işletme olarak faaliyete geçmelerine birleşme (merger) denilmektedir (Sarıkamış, 2003:3-13). Şirket satın almaları (acquisition) ise, bir işletmenin tamamını ya da belli bir kısmını satın alarak o işletmenin yönetiminde hak sahibi olmak olarak tanımlanabilir (Sarıkamış, 2003:3-13). Burada birleşmede olduğu gibi alıc1 şirketin ve hedef şirketin kimlik ve tüzel kişiliği sona ermez. Sadece satın alan işletmenin tam veya kısmı hisselerinin mülkiyetinin sahipliği alıcı firmaya geçer ve dolayısıyla satın alma oranına göre yönetim alıcı şirketin kontrolünde olur. Bu çalışmanın odak noktasını sadece satın alma faaliyetleri oluşturmaktadır.

Satın almalar genellikle yatay, dikey, farklı sektörler arası (ilişkisiz) ve sınır ötesi satın almalar olarak gerçekleştirilir. Yatay birleşme ve satın almalar, aynı sektörde faaliyet gösteren iki rakibin bir araya gelmesi ve birinin diğerini satın alması olarak tanımlanabilir (Gaughan, 2015:15). Yatay birleşen firmaların pazar güçlerini arttırıp tekelciliğe neden olabilecekleri düşüncesiyle bazı ülkelerde buna yönelik kısıtlayıcı politikalar uygulanabilmektedir. Devlet kurumları, firmaların satın alma sonrası fiyatları tek taraflı olarak arttırıp arttırmadığına bakarken aynı zamanda pazardaki diğer firmalarla karşılıklı anlaşma yapıp yapmadıklarını da incelemektedir (Morresi ve Pezzi, 2014:74).

Dikey satın almalar alıcı-satıcı ilişkisine sahip firmalar arası gerçekleştirilir (Gaughan, 2015:15). Tedarikçisini satın alan firmalar geri doğru dikey satın alma, müşterisini satın alan firmalar ise ileriye doğru dikey satın alma gerçekleştirmiştir. Firmalar aynı zamanda dikey birleşme ve satın almalarla değer zincirini kontrol edebilmek ve pazar gücünü arttırmak isterler (Morresi ve Pezzi, 2014:96). Bunun yanı sıra önemli bir tedarikçiyi satın almak; hammadde temini, maliyetleri düşürmek, zamanında teslimat ve yüksek kaliteli ürünlere erişimi kolaylaştırmaktadır. Özellikle tedarikçi sayısının az olduğu durumlarda bu faydalar artabilir. Tedarikçilerle çalışmanın pahalı, problemli ve bazen mümkün olmadığı düşünüldügünde dikey satın alma, işlem maliyetlerinin hızlı bir şekilde düşmesini sağlar. Dikey satın almalar yatay satın almalar kadar fiyatları etkileme noktasında çok fazla bir etkiye sahip olmadıkları için rekabet kurumları tarafından aşırı düzenlemeye tabi değildir.

Farklı sektörler arasında gerçekleşen birleşme ve satın almalarda ise firmalar ne rakiplerini ne de tedarik zincirindeki bir firmayı satın alır (Gaughan, 2015:15). Farklı sektörler arasında gerçekleşen satın almalar sermaye maliyetlerini ve giderleri azaltırken verimliliği arttırır. Çünkü firmalar iki bağımsız piyasada yer alır ve dolayısıyla birbirlerinin rakipleri değildir. Firmaları farklı sektörlerde satın almalara iten en önemli nedenler; yeni pazarlara erişim ve büyüme, sistematik olmayan riski azaltmak ve sinerji yaratmak olarak sıralanabilir (Moresini ve Pezzi, 2014:97).

\subsection{Satın Alma Nedenleri}

Şirketleri satın almaya iten birçok sebep olabilir. Firmanın tarihsel geçmişi (Finkelstein, 1997:787), sektörel çevresi (Hitt ve Tyler, 1991:327), çevresel dinamizm (Heeley vd., 2006:1513), egemen kurumsal normlar (Palmer ve Barber, 2001:87) ve içsel değerlendirmeler (Campling ve Michelson, 1998:579) gibi firmaları satın almayı yönelten birçok sebep olabilir. Ancak teoride satın alma faaliyetlerini açıklarken, firmaları satın almaya iten belli başlı nedenler olduğu görülmektedir. İlk olarak, firmalar sinerji yaratmak için başka bir firmayı satın alma yoluna gidebilirler (Gaughan, 2015:138). Örneğin, iyi yönetilmeyen ancak potansiyeli olan bir firmay1 satın alan bir şirket, kendi yönetsel becerilerini kullanarak bu firmanın verimliliğini arttırabilir. Benzer şekilde, firmalardan birinin çok iyi ürünleri olsun, diğerinin ise dağıtım ağı çok güçlü olsun. Bu iki firmanın birleştikten sonra yarattığı sinerji oldukça fazla olacaktır.

İkinci olarak firmalar, pazar paylarını arttırmak için başka bir firmayı satın alabilirler (Morresi ve Pezzi, 2014:96). Rakiplerin satın alındığı durumlarda piyasadaki oyuncuların sayısı azalacağı için, pazar payında artış olacaktır. Hitt vd. (2001) tarafından yapılan bir çalışmada, aynı sektör içinde sınır-ötesi gerçekleştirilen şirket birleşme ve satın almaların, pazar gücünü arttırmak adına firmalar tarafından kullanılan stratejik bir araç olduğu kabul edilmektedir. Çünkü satın alma yaparak pazar gücünü arttıran firmalar, piyasa fiyatlarını etkileyebilir ve rekabet avantaj1 elde edebilir.

Firmalar aynı zamanda yetenek kazanmak ve kaynaklarını genişletmek için de satın alma faaliyetleri gerçekleştirebilir (Morresi ve Pezzi, 2014:97). Birleşme ve satın almalar aracılı̆̆ıyla firmalar değerli, kıt, ikame 
edilemeyen ve taklit edilemeyen kaynakları ve yetenekleri elde ederek rekabet avantajı elde etmeye çalışabilir. Şirket satın almaları yeni bilgi ve becerileri elde etmek ve var olan kaynakları genişletilmesi gibi firmaya birçok firsat sunar. Örneğin, sahip olmadığı bir teknolojiyi üretmek yerine o teknolojiye sahip bir firmayı satın almak daha hızlı bir yöntem olarak görülebilir.

Satın almalar yabancı bir pazara girmek için kullanılan en hızlı yoldur (Morresi ve Pezzi, 2014:99). Firmalar yabancı bir pazarda yeni bir ürün üretmenin ne kadar süreceğini tahmin etmede zorlanabilir. Dolayısıyla satın almalar bu süreci kısaltabilir. Shimizu vd. (2004:307) tarafından yapılan bir çalışmada sıfırdan yeni bir yatırım yapmaktansa birleşme ve satın alma yapmanın bir pazara giriş için daha hızlı bir yol olduğunu belirtmektedir. Özellikle kısıtlı bir zaman içinde yeni bir pazara nüfus etmesi gereken firmalar için satın alma faaliyetleri oldukça önemlidir.

Coğrafi çeşitlendirme de şirketleri satın almaya iten önemli nedenlerden biridir. Lu ve Beamish (2004:598)'e göre, coğrafi çeşitlenme firmaların ölçek ekonomisini kullanmasını sağlar. Böylelikle firmalar, riski farklı ülkelere yayarak gelir dalgalanmalarını azaltırken pazar gücünü ve karını arttırıp maliyetleri düşürebilir. Başka bir deyişle, firmalar mevcut pazarlarından daha karlı olan ve büyüme potansiyeli olan pazarlara girmek için çeşitlenebilirler.

\subsection{Sınır Ötesi Şirket Satın Alma}

Satın alma faaliyetindeki taraf şirketler farklı ülkelerden ise buna sınır-ötesi şirket birleşme ve satın almaları (Cross-border Merger and Acquisition) denilmektedir (Shimizu vd., 2004:309). Sınır-ötesi yapılan satın almalar ise yabancı bir ülkede yer alan bir şirketin tamamının veya belli bir kısmının satın alınması olarak tanımlanabilir (Hitt vd., 2001:146). Son yıllarda giderek artan sınır-ötesi birleşme ve satın almalar uluslararası şirketlerin büyümesi için stratejik bir araç olarak görülmektedir (Cartwright ve Cooper, 1993:57). Dünya yatırım raporuna göre (2016), sınır-ötesi şirket birleşmeleri yıllar itibariyle giderek artan bir eğilim göstermektedir. 2008'deki küresel kriz ile birlikte satın alma sayısı azalmasına rağmen, sınır-ötesi satın alma değeri 2014 yılında 432 milyar dolardan 2015 yılında 721 milyar dolara ulaşmıştır. Bu raporda Batı Asya'da en fazla yatırım yapılan ülke olarak görülen Türkiye'nin yerine bakacak olursak 2015 yılı içinde yapılan satın alma ve birleşme değeri 17 milyar dolara çıkmış ve bir önceki yıla göre \%36 artmıştır. Bu durum Türkiye'yi gelişmekte olan Asya bölgesi içinde en fazla yatırım yapılan beşinci ülke konumuna getirmiştir. Dolayısıyla örgütlerin bu kadar fazla ilgi gösterdikleri bir alan olan şirket birleşme ve satın alma faaliyetleri ile ilgili Türkiye'nin genel çerçevesini çizen bir araştırma yapmak kaçınılmaz olmaktadır. Özellikle şirketlerin uluslararasılaşması ve yurt dışında yatırım yapma yöntemi olarak gördükleri sınır ötesi satın alma uygulamaları bu çalışmanın ana odağını oluşturmaktadır (Dünya Yatırım Raporu, 2016:43).

Sınır-ötesi şirket satın almalar, uluslararasılaşmak isteyen işletmelerin tercih ettiği yollardan birisidir. Kendi ülkelerinde başarılı bir şekilde faaliyetlerini sürdüren şirketler daha fazla kâr ve gelir için sınır-ötesi şirket satın alma yapabilirler. Kendi ülkelerinde büyümeye gitmekten ziyade, şirketler sınır-ötesi satın alma yaparak başka bir pazara erişim imkâni elde ederler. Alıcı şirket yaptığı sınır-ötesi işlemlerde, hedef şirketin ülkesine ait spesifik bilgileri (know- how), mevcut çalışanı ve dağıtım ağını kullanabilir.

Firmaların ülke dışına yaptıkları yatırımlar her geçen yıl artmaktadır. Bölgesel farklılaşma ya da ürün farklılaşması yapmak isteyen firmalara firsat yaratması, bunun en önemli nedeni olarak gösterilmektedir (Hitt vd., 2001:125). Genel olarak ise sınır-ötesi satın almalar yeni bir pazara girmek için hızlı bir yoldur. Şirketler, pazarda daha hızlı bir şekilde yer edinir. Stratejik işbirlikleri ve ortak girişimlere nazaran daha fazla kontrolün olduğu bir yatırım biçimidir (Angwin ve Sav1ll, 1997:427). Hitt vd.' ne (2001:150) gore uluslararası bir şirketle birleşmenin veya satın almanın beş önemli nedeni vardır. Bunlar; pazar gücü elde etme, giriş engellerinin üstesinden gelmek, yeni ürün geliştirme maliyetleri, pazara hızlı giriş ve ürün çeşitlendirmedir.

İşletmeler küreselleşmenin etkisiyle, yurt dışındaki firsatlardan yararlanmak ve aynı zamanda kurumsal baskılardan dolayı sınır-ötesi şirket birleşme ve satın alma yapabilirler (Hitt, 2000:6; Hitt vd., 1998:91). Ancak, sınır-ötesi satın almalarda şirketlerin karşılaşacağı bazı zorluklar vardır (Child vd., 2001). Hatta bazı çalışmalarda bu sürecin başarısız olduğu yönünde bulgular mevcuttur. KPMG (1997-1998) tarafindan yapılan bir araştırmaya göre, sadece \%17 sınır-ötesi şirket birleşmesi-satın alması değer yaratırken, \%53'unun değer kaybettirdiği görülmüştür.

Sınır-ötesi şirket birleşmeleri, yeni ve kazançlı pazarlara erişim ve pazar genişletme için kullanılabilir. Martin vd.'ne (1998:566) göre tedarikçiler uluslararası büyümede genellikle müşterilerini satın almaya çalışırlar. Bu stratejik hamlenin en önemli nedeni, uluslararası müşterileri satın aldıkları zaman yerel tedarikçilerin kendilerini 
tehdit altında hissetmesini sağlamaktır. Böylelikle, uluslararası birleşme ve satın alma yeni bir firsat yaratmak ya da gelecek tehditleri önlemek için yapılabilir.

\subsection{Türkiye'de Satın Alma İşlemleri}

Türkiye, dünyada en hızlı gelişen pazarlardan biri olup, birleşme ve satın alma faaliyetlerinde de yüksek bir büyüme oranına sahiptir. Türkiye ekonomisi 1990'larda liberalleştirmeye başlamış ve 2001-2002 krizinden sonra, ülke içinde ve dışında doğrudan yabancı yatırım ve sermaye akışı çekmeye başlamıştır. Türkiye, teknolojik altyapısını geliştirmiş ve ülkenin Asya ile Avrupa'yı birbirine bağlayan çekici konumuna ek olarak kurumsal politika önlemlerini yeniden düzenlemiştir. 2016 yılında Türkiye, Ar-Ge ve inovasyonla ilgili faaliyetler için kapsamlı bir destek paketi başlatmıştır. Bu durum, ülkeyi hızla büyüyen diğer gelişmekte olan pazarlar arasında önemli bir B\&S (birleşme ve satın alma) oyuncusu haline getirmiş ve ülke, işlem sayıları ve değerleri açısından satın alma faaliyetlerinde önemli bir büyümeye tanık olmuştur. Birçok Türk şirketi birleşme ve satın alma faaliyetlerinde bulunur, çeşitli anlaşmalar yapar, ticari faaliyetlerini uluslararasılaştırır, ihracatı / ithalatı arttırır. Bunlar, Türkiye'nin ekonomik büyümesini yönlendiren önemli faktörler olarak sıralanabilir. Dolayısıyla, birleşme ve satın alma son otuz yıl içinde hem yerli hem de yabancı yatırımcıların artan ilgisi sonucu giderek artan bir eğilim göstermiştir. Örneğin, Batı Asya'daki büyük doğrudan yabanc1 yatırım alıcılarından biri olan Türkiye, 2007-2015 döneminde alt bölgeye toplam girişlerin dörtte birinden fazlasını oluşturmuştur (Dünya Yatıım Raporu, 2018:186). Kriz dönemlerinde sınır ötesi satın alma işlem sayısının azaldığı görülse de genel olarak artan eğilimin söz konusu olduğu söylenebilir.

\section{TÜRKIYYE'DE 1998 - 2018 YILLARINDA GERÇEKLEŞTİRILEN SINIR ÖTESİ ŞİRKET SATIN ALMA İŞLELERI ALAN ARAŞTIRMASI}

\section{1. Çalışmanın Metodolojisi}

$\mathrm{Bu}$ araştırmayı geçmiş çalışmalardan ayıran birçok farklı özellik vardır. Örneğin, çalışmanın kapsamı Alhanhanah vd.'nin (2019:1) çalışmasından farklı olarak 20 yıl gibi uzun bir dönemi içerir. Diğer bir özellik ise, yerel satın almaları araştırma dışı bırakarak sadece sınır ötesi şirket satın alma işlemlerini araştırmaya dâhil etmesidir. Bunun yanı sıra, Genç ve Kalkan (2018:791) tarafından yapılan kapsamlı araştırmaya katkı sunması açısından, bu çalışmada Zephyr denilen farklı bir veri kaynağı kullanılmış ve örneklem sayısının artırılması ile geçmiş çalışmalarla karşılaştırma yapma olanağı sunulmuştur.

Bu çalışmada uluslararası şirket satın alma ile ilgili tüm bilgiler Zephyr isimli veri tabanından elde edilmiştir. Zephyr, tüm dünyada gerçekleşen birleşme ve satın alma, halka arz, özel sermaye ve risk sermayesi anlaşmaları ve söylentileri gibi birçok bilgiyi içeren kapsamlı bir veri kaynağıdır. Daha önce Türkiye bağlamında da çalışan bazı çalışmada kullanılan bir veri kaynağıdır (Yıldırım, 2017:285).

$\mathrm{Bu}$ çalışmada kullanılan veriler Mart 2019 yılında ilgili veri tabanından indirilmiştir. Veriler indirilirken yapılan satın almalarda öncelikle uygulanan ilk kriter 1998-2018 tarihleri arasında sınır-ötesi satın almanın gerçekleşmiş olmasıdır. Başka bir ifade ile ulusal olan tüm satın almalar elenmiş, uluslararası olanlar örnekleme dâhil edilmiştir. Daha sonra satın alma taraflarından birinin Türkiye'den bir şirket olması gerekiyordu. Bu taraf, ya hedef şirket ya da alıcı şirketin Türk olması anlamına gelmektedir. Daha sonra oluşan veri setinden; tamamlanmamış, sadece söylenti olarak kalmış ve iptal edilmiş satın alma faaliyetleri örneklem dışında bırakılarak sadece tamamlanmış olanlar çalışmaya dâhil edilmiştir. Sonuç olarak, hedef şirketin Türk, alıcı şirketin yabancı olduğu örneklem sayısı 883 satın alma işlemi olarak karşımıza çıkmaktadır. Bunun yanında, hedef şirketin yabanc1 ama alıcı şirketin Türk olduğu örneklem sayısı ise 275 olarak karşımıza çıkmaktadır. Yıllar belirlenirken satın alma işlemlerinin duyurulma tarihi değil tamamlanma tarihi baz alınmıştır. Sektörel farklılıklar veri setinde yer alan SIC kodlarına (4 haneli) göre analiz edilmiştir. Eğer hedef şirket ve alıcı şirketin SIC kodu aynı ise yatay satın alma, değilse yatay olmayan satın alma olarak sınıflandırılmıştır. Genel olarak veri setinde gizlenen veya yer almayan bilgiler analiz dışı bırakılmıştır. 


\section{2. Çalışmanın Bulguları}

Aşağıda Türk şirketlerin taraf olduğu 1998-2018 yılları arasında gerçekleşen şirket satın alma işlemleri hakkında genel bulgulara yer verilmiştir. Araştırmanın amacında da belirtildiği gibi bu çalışmada, taraflardan birinin Türk olduğu sınır-ötesi şirket satın almaları hakkında genel bir çerçeve çizilmeye çalışılmıştır. Bu doğrultuda, satın almaya konu olan ülkelerin neler olduğu, hangi yıllarda kaç tane işlem yapıldığı, işlemin büyüklüğü, satın alma oranı, şirketlerin halka açı olup olmaması, faaliyet gösterdikleri sektör ve yatay ve yatay olmayan satın almalar gibi birçok tanımlayıcı istatistiğe yer verilmiştir.

\subsubsection{Hedef Şirketin Türk, Alıcı Şirketin Yabancı Olduğu Satın Alma Faaliyetlerine İlişkin Bulgular}

Hedef şirketin Türk, alıcı şirketin yabancı olduğu satın alma faaliyetlerine ilişkin satın alma işlemlerine ait genel istatistikler Tablo 1'de gösterilmiştir.

Tablo 1. Satın Alma İşlemlerine Ait Genel İstatistikler

\begin{tabular}{|c|c|c|}
\hline & İşlem Sayısı & Yüzde \\
\hline \multicolumn{3}{|l|}{ Satın alma oranı } \\
\hline Tam satın alma (\%100) & 234 & $26.50 \%$ \\
\hline Kısmi satın alma (\%100’den az) & 569 & $64.44 \%$ \\
\hline Belirtilmeyen & 80 & $9.06 \%$ \\
\hline \multicolumn{3}{|l|}{ Daha önce aynı sirkete yatırımı olanlar } \\
\hline Daha önce aynı şirkete yatırım yapanlar & 159 & $18.01 \%$ \\
\hline İlk defa bu şirkete yatırım yapanlar & 411 & $46.55 \%$ \\
\hline Belirtilmeyen & 313 & $35.45 \%$ \\
\hline \multicolumn{3}{|l|}{ Halka açk hedef șirket } \\
\hline Daha önce halka açık olup daha sonra borsadan çıkan & 34 & $3.85 \%$ \\
\hline Halka açık & 161 & $18.23 \%$ \\
\hline Halka açık olmayan & 688 & $77.92 \%$ \\
\hline \multicolumn{3}{|l|}{ Halka açık alıcı şirket } \\
\hline Daha önce halka açık olup daha sonra borsadan çıkan & 85 & $9.63 \%$ \\
\hline Halka açık & 277 & $31.37 \%$ \\
\hline Halka açık olmayan & 521 & $59.00 \%$ \\
\hline \multicolumn{3}{|l|}{ Sektörel benzerlik } \\
\hline Yatay satın alma & 228 & $25.82 \%$ \\
\hline Yatay olmayan satın alma & 651 & $73.73 \%$ \\
\hline Belirtilmemiş & 4 & $0.45 \%$ \\
\hline Genel Toplam & 883 & $100.00 \%$ \\
\hline
\end{tabular}

Tablo 1'e göre, Türkiye'de satın alma yapan şirketler genel olarak kısmı satın alma yoluna gitmişlerdir. Başka bir ifade ile, bir Türk şirketinin tamamını satın almak yerine belli bir oranda satın almayı tercih etmiştir. Bu tabloda dikkat çeken bir başka nokta ise, bir şirkete yatırım yapan yabancı bir firmanın, daha önce aynı şirkette bir hissesi olup olmamasıdır. Bu açıdan verilere bakılırsa, yatırım yapan firmaların \%18'i daha önce aynı şirkete yatırım yapmış ve hisselerini arttırmak için tekrar satın alma yoluna gitmişlerdir. Buna karşın, yatıım yapılan şirketin ilk defa hisseleri satın alınıyor ise bu oranın \%46 olduğunu görmekteyiz. Ayrıca yapılan sıklık analizinde, hedef şirketin yaklaşık \%18'i halka açık iken, alıcı şirketin halka açık olma oranı \%31'dir. 
Hem alıcı firmanın hem de hedef firmanın büyük bir çoğunluğunun halka açık olmadığını görmekteyiz. Bahsedilmesi gereken bir başka önemli nokta, satın alma yapan taraflar arasındaki sektörel benzerliktir. Tabloya göre, alıcı firmalar satın alma yaparken yaklaşık \%73 oranda hedef şirketin farklı bir sektörde faaliyet göstermesini tercih ederken, şirketlerin sadece 228'I (\%25) aynı sektörde faaliyet gösteren bir başka şirketi satın alma yoluna gitmişlerdir. Yani 20 yıllık dönem içerisinde, yatay olmayan satın almaların sayısı yatay gerçekleştirilen satın alma sayısından fazladır.

Grafik 1. Yıllara Göre Satın Alma İşlem Sayısı

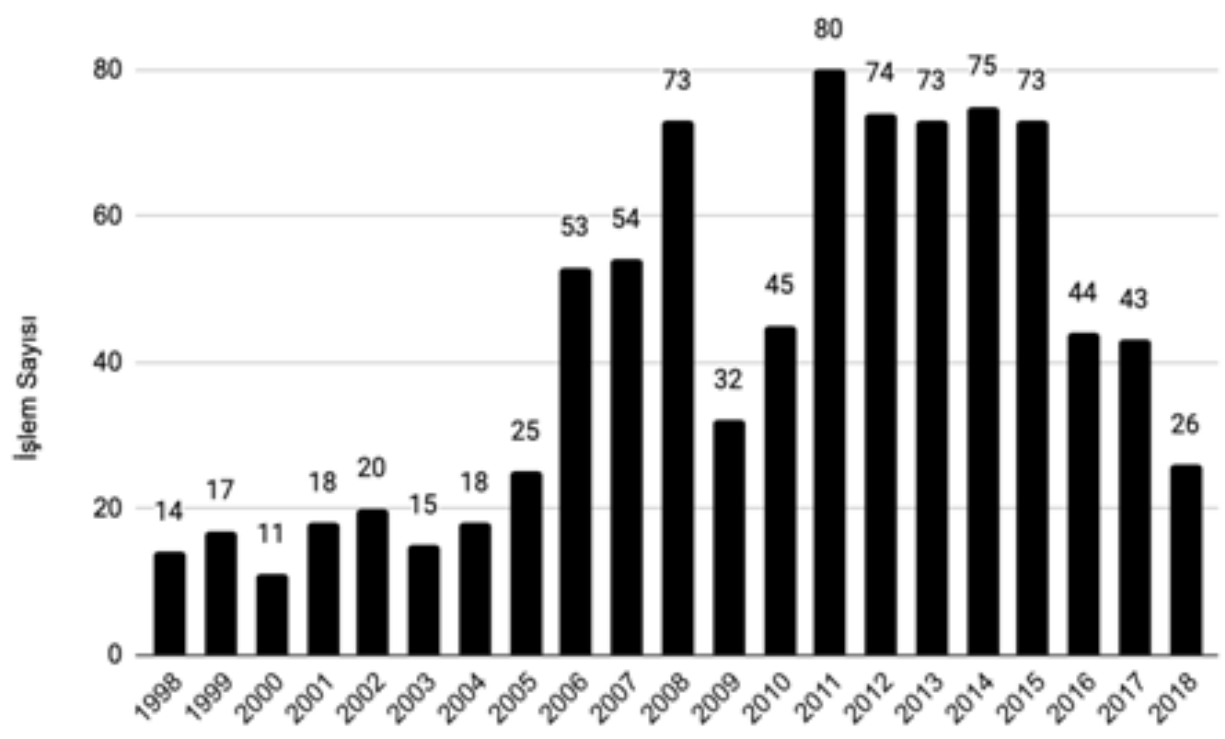

Grafik 1'de görüldüğü gibi, en fazla işlemin 2011 yılında 80 satın alma ile yapıldığı görülmektedir. Hatta genel olarak tabloya baktığımızda 2011 ile 2015 yılları arasındaki 5 yıllık dönemin yapılan satın almaların, toplam işlemlerin yaklaşık \%42' sini oluşturduğunu söyleyebiliriz. En az satın alma işleminin 11 işlem ile 2000 y1lında yapıldığı görülmektedir. Tabloda dikkat çeken bir diğer nokta ise 1998 ile 2005 yılları arasında toplamda 138 işlem yapılmıştır. Bu 8 yıllık dönemde toplam işlemlerin sadece \%16's gerçekleştirilmiştir. Aynı zamanda 2008 krizi ile birlikte, Türkiye'ye gelen yatırımcı sayısı 2009 y1lında 73'ten 32'ye düşmüştür. Yine bir başka önemli nokta, 2016 yılından itibaren düşen bir trend olmasıdır. 2018 yılında son 12 yılın en düşük işlem sayısı gerçekleşmiştir.

Tablo 2. Ülkelere Göre Alıcı Şirketlerin Faaliyet Gösterdikleri Ülkelerin Dağılımı

\begin{tabular}{|c|c|c|}
\hline Ülke & İşlem Sayısı & Yüzde \\
\hline Amerika Birleşik Devletleri & 120 & $13.59 \%$ \\
\hline İngiltere & 95 & $10.76 \%$ \\
\hline Almanya & 84 & $9.51 \%$ \\
\hline Hollanda & 78 & $8.83 \%$ \\
\hline Fransa & 61 & $6.91 \%$ \\
\hline Avusturya & 32 & $3.62 \%$ \\
\hline İtalya & 27 & $3.06 \%$ \\
\hline Lüksemburg & 25 & $2.83 \%$ \\
\hline Yunanistan & 24 & $2.72 \%$ \\
\hline Cayman Adaları & 22 & $2.49 \%$ \\
\hline İspanya & 22 & $2.49 \%$ \\
\hline İsveç & 22 & $2.49 \%$ \\
\hline
\end{tabular}


AYAS, Sibel - Sınır Ötesi Şirket Satın Alma İşlemlerine Genel Bakış: 1998 - 2018 Dönemi Türk Şirketleri Üzerine Bir İnceleme

\begin{tabular}{|c|c|c|}
\hline Birleşik Arap Emirlikleri & 22 & $2.49 \%$ \\
\hline İsviçre & 20 & $2.27 \%$ \\
\hline Japonya & 19 & $2.15 \%$ \\
\hline Belçika & 18 & $2.04 \%$ \\
\hline Kuveyt & 14 & $1.59 \%$ \\
\hline Katar & 14 & $1.59 \%$ \\
\hline Polonya & 12 & $1.36 \%$ \\
\hline Rusya & 12 & $1.36 \%$ \\
\hline Azerbaycan & 11 & $1.25 \%$ \\
\hline Suudi Arabistan & 10 & $1.13 \%$ \\
\hline Diğerleri & 119 & $13.48 \%$ \\
\hline Genel Toplam & $\mathbf{8 8 3}$ & $\mathbf{1 0 0 . 0 0 \%}$ \\
\hline
\end{tabular}

Toplamda 61 farklı ülkeden bir şirket Türkiye'de bir şirketi satın almıştır (Ayrıntılı tablo için Ek 1'e bakınız). Tablo 2'de görüldüğü üzere Türkiye'ye en fazla yatırım yapan ülke 120 işlem ile Amerika'dır. Hatta genel çerçeveye bakacak olursak tüm işlemlerin \%50 sini ilk sıradaki 5 ülke oluşturmaktadır (Bunlar sırasıyla, Amerika Birleşik Devletleri, İngiltere, Almanya, Hollanda, Fransa). En fazla yatırım yapan ülkelerin gelişmiş ülkeler oldukları da dikkat edilmesi gereken bir başka nokta olarak gösterilebilir. Arap ülkelerinin yatırım oranlarına bakacak olursak, Birleşik Arap Emirlikleri 22 işlem sayısı ile en fazla yatırım yapan arap ülkesidir. Bunu 14 işlem ile Kuveyt ve Katar takip etmektedir. Suudi Arabistan'ın ise bu yirmi yıllık dönemde Türkiye'ye yaptığı toplam yatırım sayısının 10 olduğu gözükmektedir. Vergi cenneti sayılan Cayman Adasından ülkemize 22 satın alma işlemi yapılmıştır. Uzak doğu ülkesi olan Japonya ise 19 satın alma işlemi gerçekleştirmiştir.

Grafik 2. Yıl Bazında Açıklanan Firma Satın Alma Hacmi (Milyon Euro)

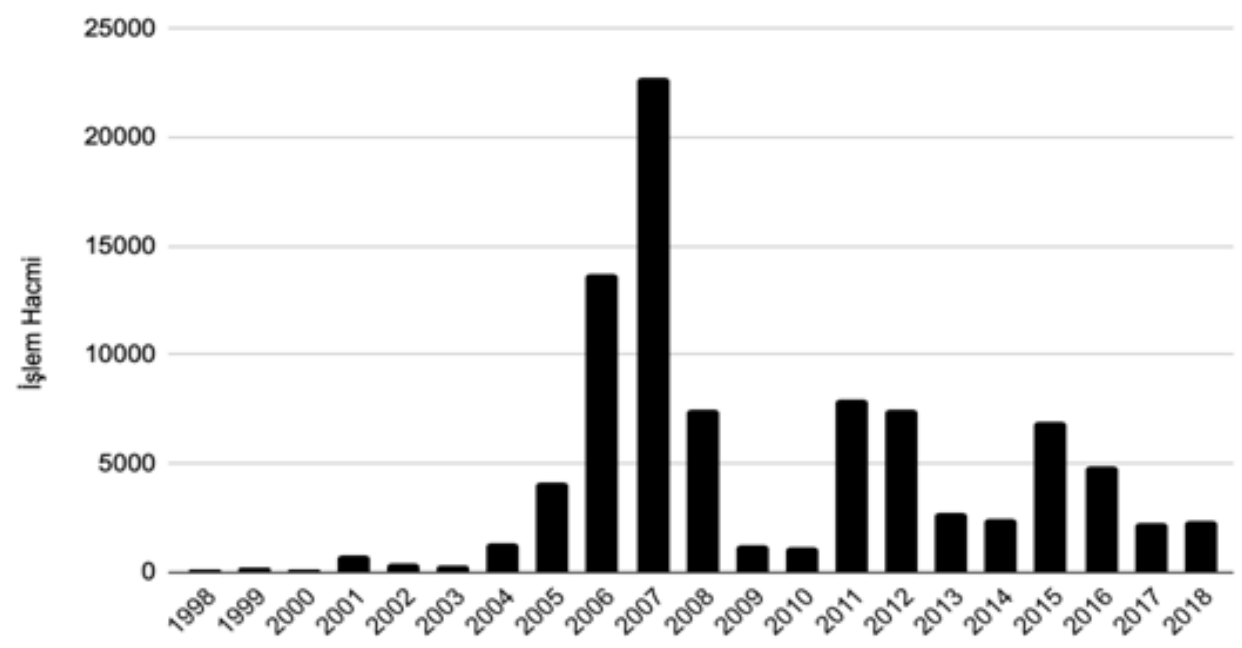

Toplam 883 işlemin sadece 454 tanesinin satın alma değeri ilan edilmiştir. Dolayısıyla yukarıda oluşturulan Grafik 2'de 454 işlemle ilgili istatistiki bilgiler yer almaktadır. Grafikte görüldüğü gibi, son yirmi yılda yabancı şirketlerin Türkiye'de yaptıkları satın alma trendine bakıldığında ilk dikkat çeken nokta, satın alma hacminin en yüksek olduğu yıl olan 2007'dir. Bunun nedeni ise 2007 yılında gerçekleştirilen Finansbank'ın Yunan şirketi olan National Bank of Greece'ye satılmasıdır (17 milyar Euro). Hatta bu satın alma, çalışmanın kapsadığı yıllar içerisindeki değeri açıklanan en büyük hacimli satın alma işlemi olarak da dikkat çekmektedir. Grafikte dikkat çeken bir başka nokta ise satın alma hacminin 2004 yılına kadar durağan bir seyir izlemesidir. 2006 y1lı itibariyle ciddi bir oranda artmaya başlayan satın alma işlem hacmi, 2008 y1lında düşüşe geçmiştir. 2009-2010 arası dönemde durağan seyreden eğilim, 2011 yılından 2018 yılına kadar olan süre içerisinde dalgalanmalara söz konusu olmuştur. 
Tablo 3. İşlem Sayısına Göre Hedef ve Alıcı Şirketlerin Ana Faaliyet Alanları

\begin{tabular}{|c|c|c|c|c|c|}
\hline \multirow{2}{*}{ SIC Kodları } & \multirow{2}{*}{ Sektör } & \multicolumn{2}{|c|}{ Hedef Şirket } & \multicolumn{2}{|c|}{ Alıcı Şirket } \\
\cline { 2 - 6 } & & İşlem Sayısı & Yüzde & İşlem Sayısı & Yüzde \\
\hline $0100-0999$ & Tarım, ormancılık ve balıkçılık & 27 & $3.06 \%$ & 13 & $1.47 \%$ \\
\hline $1000-1499$ & Belirtilmemiş & 1 & $0.11 \%$ & 3 & $0.34 \%$ \\
\hline $1500-1799$ & İnşaat & 4 & $0.45 \%$ & 7 & $0.79 \%$ \\
\hline $1800-1999$ & Finans, sigorta ve gayrimenkul & 148 & $16.76 \%$ & 354 & $40.09 \%$ \\
\hline $2000-3999$ & İmalat & 294 & $33.30 \%$ & 253 & $28.65 \%$ \\
\hline $4000-4999$ & Madencilik & 15 & $1.70 \%$ & 27 & $3.06 \%$ \\
\hline $5000-5199$ & Kamu yönetimi & 1 & $0.11 \%$ & 3 & $0.34 \%$ \\
\hline $5200-5999$ & Perakende satış & 64 & $7.25 \%$ & 28 & $3.17 \%$ \\
\hline $6000-6799$ & Hizmet sektörü & 163 & $18.46 \%$ & 112 & $12.68 \%$ \\
\hline $7000-8999$ & Ulaşım, iletişim, elektrik, gaz vb hizmetleri & 99 & $11.21 \%$ & 57 & $6.46 \%$ \\
\hline $9100-9729$ & Toptan satış & 67 & $7.59 \%$ & 26 & $2.94 \%$ \\
\hline & Genel Toplam & $\mathbf{8 8 3}$ & $\mathbf{1 0 0 . 0 0 \%}$ & $\mathbf{8 8 3}$ & $\mathbf{1 0 0 . 0 0 \%}$ \\
\hline
\end{tabular}

Yukarıdaki Tablo 3, her bir firmanın kendine ait olan 4 haneli SIC koduna göre düzenlemiştir. Buna göre 20 yıllık süre içerisinde en fazla yatırım yapılan sektör (hedef şirketin faaliyet alanı), \%33 oranı ile imalat sektörüdür. Bunu \%18 ile hizmet sektörü ve \%16 ile finans sektörü takip etmektedir. Alıcı şirketlerin en az yatırım yaptıkları sektörler ise, kamu yönetimi $(\% 0,1)$, yapı/inşaat sektörü $(\% 0.4)$ ve madencilik $(\% 1.7)$ alanlarıdır. Diğer taraftan, alıcı şirketin istatistiklerine bakılırsa, Türkiye'ye en fazla yatırım yapan sektörün finans sektörü olduğu görülecektir (\%40). Finans sektöründeki hedef şirket sayısının alıcı şirket sayısından az olması, finans şirketlerin büyük bir çoğunluğunun yatay olmayan satın alma işlemi gerçekleştiğini göstermektedir. En fazla yatırım yapan ikinci sektör ise \%28 oranla imalat sektörü yer almaktadır. Alıcı şirketlerin en az faaliyet gösterdikleri sektörler hedef şirketlerin en az faaliyet gösterdikleri sektör ile aynıdır.

Tablo 4. En Fazla Yatırım Yapılan Alt Sektörler

\begin{tabular}{|c|c|c|c|c|c|c|c|}
\hline \multicolumn{4}{|c|}{ Hedef Şirket } & \multicolumn{4}{|c|}{ Alıcı Şirket } \\
\hline $\begin{array}{c}\text { SIC } \\
\text { Kodları }\end{array}$ & Sektör & $\begin{array}{l}\text { İşlem } \\
\text { Sayısı }\end{array}$ & Yüzde & $\begin{array}{c}\text { SIC } \\
\text { Kodları }\end{array}$ & Sektör & $\begin{array}{l}\text { İşlem } \\
\text { Sayısı }\end{array}$ & Yüzde \\
\hline 6021 & Bankacilık & 46 & $5.21 \%$ & 6799 & Yatırım şirketleri & 120 & $13.59 \%$ \\
\hline 7374 & Bilgisayar işleme ve veri hazırlama & 32 & $3.62 \%$ & 6021 & Bankacılık & 54 & $6.12 \%$ \\
\hline 4911 & Elektrik hizmetleri & 24 & $2.72 \%$ & 6719 & Holdingler & 49 & $5.55 \%$ \\
\hline 7371 & Bilgisayar programlama hizmetleri & 20 & $2.27 \%$ & 6282 & Yatırım danışmanlığ 1 & 31 & $3.51 \%$ \\
\hline 6719 & Holdingler & 16 & $1.81 \%$ & 6211 & Menkul kıymet, Broker ve flotasyon şirketleri & 25 & $2.83 \%$ \\
\hline 2834 & Hidrolik çimento & 14 & $1.59 \%$ & 7374 & Bilgisayar işleme ve veri hazırlama & 18 & $2.04 \%$ \\
\hline 3241 & Farmasötik preparatlar & 14 & $1.59 \%$ & 4911 & Elektrik hizmetleri & 18 & $2.04 \%$ \\
\hline 6211 & $\begin{array}{l}\text { Menkul kıymetler, Broker ve } \\
\text { flotasyon şirketleri }\end{array}$ & 14 & $1.59 \%$ & 6311 & Hayat sigortası & 15 & $1.70 \%$ \\
\hline 4899 & İletişim hizmetleri & 13 & $1.47 \%$ & 8742 & Yönetim danışmanlık hizmetleri & 14 & $1.59 \%$ \\
\hline \multirow[t]{3}{*}{8999} & Hizmetler & 13 & $1.47 \%$ & 1311 & Ham petrol ve doğal gaz & 13 & $1.47 \%$ \\
\hline & Diğerleri & 667 & $76.67 \%$ & & Diğerleri & 526 & $59.57 \%$ \\
\hline & Genel Toplam & 883 & $100.00 \%$ & & Genel Toplam & 883 & $100.00 \%$ \\
\hline
\end{tabular}


Yukarıdaki Tablo 4'te, hedef firma sektörlerinin daha spesifik olarak belirlenmesi açısından SIC kodlarının 4 hanesi kullanılarak en fazla yatırım yapılan 10 alt sektör belirlenmiştir. Buna göre, 20 yıllık dönem içerisinde 883 alıcı şirketin 46 tanesi (\%5) ticari bankaları satın almayı tercih etmiştir. Buna karşın son yılların gözde sektörlerinden biri olan bilgisayar işleme ve veri hazırlama sektöründe toplam 32 satın alma (\%3.6) gerçekleşmiştir. Bilgisayar programlama sektörü ise 20 satın alma işlemi ile en fazla yatırım yapılan 4. sektör olarak karşımıza çıkmaktadır. Alıı firma açısından bakılırsa, Türkiye'ye gelen yatırımcıların 120 sektör ile büyük bir kısmı bağımsız yatırım şirketlerinden oluşmaktadır $(\% 13,5)$. En fazla yatırım yapan ikinci sektör ticari bankalardır ve bu alanda Türkiye'ye yatırım yapanların oranı \%6'dir (54 işlem). Bilgisayar sektöründe faaliyet gösteren alıcı firmaların sayısı ise sadece \%2'dir (18 işlem).

Grafik 3. Yatay ve Yatay Olmayan Satın Alma Sayısının Yıl Bazında Dağılımı

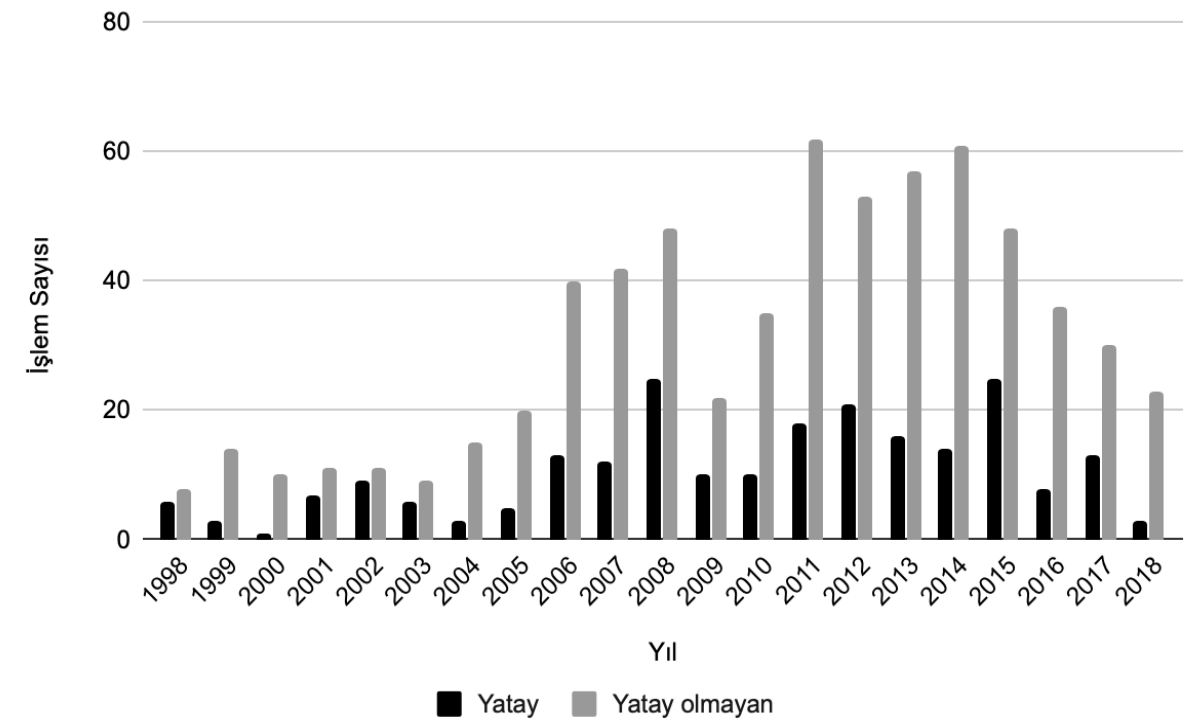

Grafik 3, 4 haneli SIC kodlarına göre sınıflandırılan sektörleri baz alarak hazırlanmıştır. Buna göre, yatay satın alma işlemi aynı sektörde faaliyet gösteren firmalar arası gerçekleşen satın alma işlemini gösterirken, yatay olmayan satın alma işlemi ise farklı sektörler arası gerçekleşen satın alma faaliyetleri anlamına gelmektedir. Genel olarak grafiğe bakıldığında, tüm yıllar açısından yatay olmayan satın alma faaliyetlerinin, yatay satın almalardan sayıca üstündür. En fazla yatay satın almanın yapıldığı yıl 2008 ve 2015 (her biri için 25 işlem) iken, yatay olmayan satın almanın en fazla yapıldığı yıl 62 işlem sayısı ile 2011 yılıdır. Bunu 2014 yılında yapılan 61 yatay olmayan satın alma faaliyeti takip etmektedir. Sayı olarak yatay olmayan satın almanın en fazla gerçekleştiği yıllar ise sırasıyla 1998 (8 işlem) ve 2003 (9 işlem) yıllarıdır.

\subsubsection{Hedef Şirketin Yabancı, Alıcı Şirketin Türk Olduğu Satın Alma Faaliyetlerine İlişkin Bulgular}

Hedef şirketin yabancı, alıcı şirketin türk olduğu satın alma faaliyetlerine ilişkin bulgular Tablo 5'te gösterilmiştir.

Tablo 5. Satın Alma İşlemlerine Ait Genel İstatistikler

\begin{tabular}{|c|c|c|}
\hline & İşlem sayısı & Yüzde \\
\hline \multicolumn{3}{|l|}{ Satın alma oranı } \\
\hline Tam satın alma (\%100) & 94 & $34.18 \%$ \\
\hline Kısmi satın alma (\%100'den az) & 160 & $58.18 \%$ \\
\hline Belirtilmeyen & 21 & $7.64 \%$ \\
\hline \multicolumn{3}{|l|}{ Daha önce aynı ssirkete yatırımı olanlar } \\
\hline Daha önce aynı şirkete yatırım yapanlar & 56 & $20.36 \%$ \\
\hline
\end{tabular}




\begin{tabular}{|l|c|c|}
\hline İlk defa bu şirkete yatırım yapanlar & 149 & $54.18 \%$ \\
\hline Belirtilmeyen & 70 & $25.45 \%$ \\
\hline Halka açk hedef șirket & 20 & $7.27 \%$ \\
\hline Daha önce halka açık olup daha sonra borsadan çıkan & 27 & $9.82 \%$ \\
\hline Halka açı & 228 & $82.91 \%$ \\
\hline Halka açı olmayan & \multicolumn{2}{|l|}{} \\
\hline Halka açı alıcı şirket & 9 & $3.27 \%$ \\
\hline Daha önce halka açı olup daha sonra borsadan çıkan & 80 & $29.09 \%$ \\
\hline Halka açı & 186 & $67.64 \%$ \\
\hline Halka açı olmayan & 94 & $34.18 \%$ \\
\hline Sektörel benzerlik & 165 & $60.00 \%$ \\
\hline Yatay satın alma & 16 & $5.82 \%$ \\
\hline Yatay olmayan satın alma & $\mathbf{2 7 5}$ & \\
\hline Belirtilmemiş & & \\
\hline Genel Toplam & & \\
\hline
\end{tabular}

Tablo 5'te hedef şirketin yabancı, alıcı şirketin Türk olduğu satın alma faaliyetlerine ilişkin bulgular yer almaktadır. Genel tabloya bakıldığında, Türk şirketlerinin büyük bir çoğunluğu (\%58) kısmı satın alma ile yurt dışına yatırım yaparken, sadece \%34'u hedef firmanın tamamını satın almıştır. Satın alma yapılan hedef şirkette daha önceden hissesi bulunanların oranı sadece \%20 iken, yaklaşık \%54'u ilk defa yatırım yapmıştır. Ayrıca, alıcı Türk şirketleri çoğunlukla halka açı olmayan hedef şirketleri satın almayı tercih etmişlerdir (228 işlem, \%82). Buna karşın alıcı şirketler açısından bu durum biraz daha farklıdır. Türk şirketlerin 186'sı halka açık olmamasına rağmen, önemli bir kısmı halka açı (80 işlem) firmalardır. Hedef şirketin yabancı, alıcı şirketin Türk olduğu satın alma işlemlerinde genellikle farklı sektörler arası satın alma tercih edilmiştir (165 işlem). Bununla birlikte, aynı sektörler arasında yapılan satın alma faaliyetleri toplam faaliyetin \%34'unu oluşturmaktadır (94 işlem).

\section{Grafik 4. Yıllara Göre Satın Alma İşlem Sayısı}

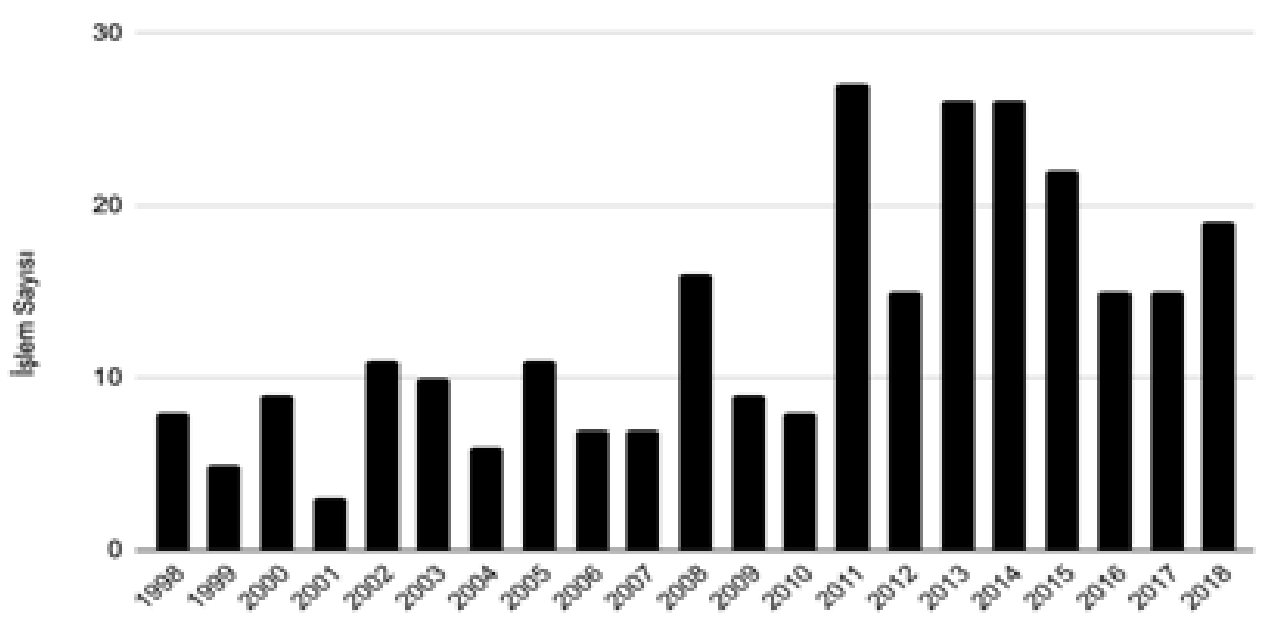

Grafik 4, toplam 20 yıllık dönemde yurt dışına gerçekleştirilen 275 işleme dayanmaktadır. Yııllara göre satın alma dağılımına bakıldığında, genel olarak dalgalı bir trend olduğunu görülmektedir. Türk firmaların yurt dışına en fazla yatırım yaptıkları yılın 27 işlem ile 2011 olduğu söylenebilir. Bunu takiben 2013 ve 2014 yılında 26 satın alma işlemi gerçekleşmiştir. Sayı olarak en az işlem 3 satın alma yapılmasıyla 2001 yılında olmuştur. Benzer şekilde 1999 yılında sadece 5 satın alma yapılmıştır. 20 yıllık döneme bakıldığında özellikle 2008 krizi sonrası bir düşüş görülse de, 2011 yılından itibaren Türk firmaların yurt dışında şirket satın alma eğiliminin arttığı görülmektedir. 
Tablo 6. Ülkelere Göre Alıcı Şirketlerin Faaliyet Gösterdikleri Ülkelerin Dağılımı

\begin{tabular}{|c|c|c|}
\hline Ülke & İşlem Sayısı & Yüzde \\
\hline Romanya & 24 & $8.73 \%$ \\
\hline Almanya & 22 & $8.00 \%$ \\
\hline İngiltere & 21 & $7.64 \%$ \\
\hline Bulgaristan & 20 & $7.27 \%$ \\
\hline Hollanda & 17 & $6.18 \%$ \\
\hline İtalya & 16 & $5.82 \%$ \\
\hline Amerika Birleşik Devletleri & 16 & $5.82 \%$ \\
\hline Rusya & 13 & $4.73 \%$ \\
\hline Fransa & 8 & $2.91 \%$ \\
\hline Ukrayna & 8 & $2.91 \%$ \\
\hline Kanada & 7 & $2.55 \%$ \\
\hline Makedonya & 6 & $2.18 \%$ \\
\hline Arnavutluk & 5 & $1.82 \%$ \\
\hline Macaristan & 5 & $1.82 \%$ \\
\hline Surbistan & 5 & $1.82 \%$ \\
\hline Avusturya & 4 & $1.45 \%$ \\
\hline Azerbaycan & 4 & $1.45 \%$ \\
\hline Hirvatistan & 4 & $1.45 \%$ \\
\hline Polonya & 4 & $1.45 \%$ \\
\hline İspanya & 4 & $1.45 \%$ \\
\hline İsviçre & 4 & $1.45 \%$ \\
\hline Özbekistan & 4 & $1.45 \%$ \\
\hline Diğerleri & 54 & $19.64 \%$ \\
\hline Genel Toplam & 275 & $100.00 \%$ \\
\hline
\end{tabular}

Tablo 6'da yer alan ülke dağılımında araştırmanın dahil edildiği 20 yıllık döneme bakıldığında, Türk firmalarının yatırım yapmak için tercih ettikleri ilk ülkenin Romanya olduğu görülmektedir. İkinci sırada 22 işlem ile Almanya, üçüncü sırada ise 21 işlem İngiltere gelmektedir. Türk firmalar ise Amerika'da 16 satın alma işlemi yapmıştır. Genel olarak tabloya bakıldığında, Türk şirketlerin tek bir ülkeye ya da bölgeye yatırım yapmadığını, çeşitli ülkelerde farklı sayılarda satın alma gerçekleştiğini görmekteyiz. Ancak yatırımların çoğunlukla Avrupa'da gerçekleştiği söylenebilir (Ayrıntılı tablo için Ek 1’e bakınız). 
Grafik 5. Yıl Bazında Açıklanan Firma Satın Alma Hacmi (Milyon Euro)

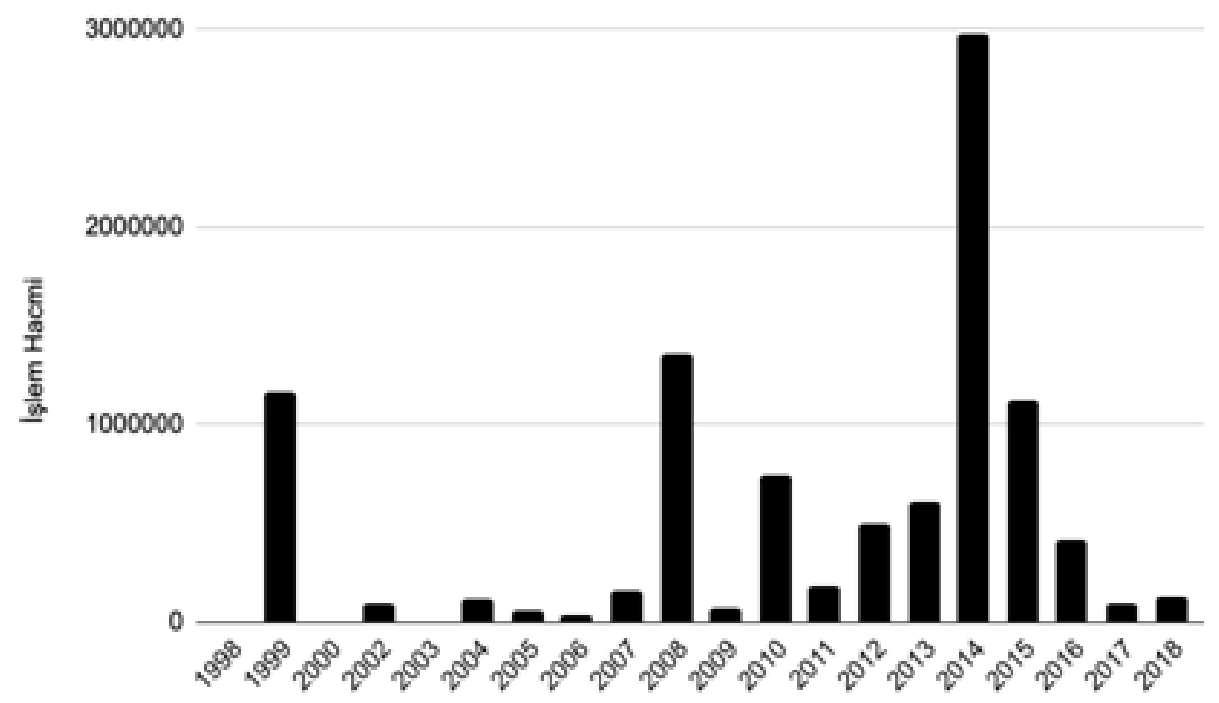

Örneklemde toplam 275 işlem yer almasına karşın, bu işlemlerden sadece 157 işlemde satın alma değeri raporlanmıştır. Buna göre Grafik 5'de, en fazla satın alma değerinin açıklandığı yıl 2014 y1lıdır (yaklaşık 2,900 milyon Euro). Bu değerin yaklaşık 2.500 milyon Eurosu Yıldız Holding'in dünyanın altıncı büyük bisküvi üreticisi İngiliz United Biscuits'i satın alması ile ilgilidir. Satın alma değerinin en düşük olduğu yıllar ise sırasıyla 1998 ve 2000 yıllarıdır. Grafikte dikkat çeken en önemli nokta, bazı yıllar satın alma değerlerinin dramatik bir biçimde düşmesidir. Örneğin, 2000, 2009 ve 2017 yıllarında satın alma değeri açısından ani düşüşlerin olduğu yıllardır. Bu yıllar genel olarak Türkiye'deki ekonomik kriz dönemleri ile ilişkilendirilebilir. Aynı zamanda, 1999, 2008 ve 2014 yılları ise satın alma değeri açısından ani çıkışların yaşandığı yıllar olarak dikkat çekmektedir.

Tablo 7. İşlem Sayısına Göre Hedef ve Alıcı Şirketlerin Ana Faaliyet Alanları

\begin{tabular}{|c|c|c|c|c|c|}
\hline SIC kodları & Sektör & İşlem sayısı & Yüzde & İşlem sayısı & Yüzde \\
\hline $0100-0999$ & Tarım, ormancılık ve balıkçılık & 2 & $0.73 \%$ & 0 & $0.00 \%$ \\
\hline $1000-1499$ & Belirtilmemiş & 1 & $0.36 \%$ & 15 & $5.45 \%$ \\
\hline $1500-1799$ & İnşaat & 2 & $0.73 \%$ & 1 & $0.36 \%$ \\
\hline $1800-1999$ & Finans, sigorta ve gayrimenkul & 47 & $17.09 \%$ & 93 & $33.82 \%$ \\
\hline $2000-3999$ & İmalat & 104 & $37.82 \%$ & 93 & $33.82 \%$ \\
\hline $4000-4999$ & Madencilik & 16 & $5.82 \%$ & 7 & $2.55 \%$ \\
\hline $5200-5999$ & Perakende satış & 11 & $4.00 \%$ & 7 & $2.55 \%$ \\
\hline $6000-6799$ & Hizmet sektörü & 31 & $11.27 \%$ & 9 & $3.27 \%$ \\
\hline $7000-8999$ & Ulaşım, iletişim, elektrik, gaz vb. & 49 & $17.82 \%$ & 41 & $14.91 \%$ \\
\hline $9100-9729$ & Toptantleri satış & 12 & $4.36 \%$ & 9 & $3.27 \%$ \\
\hline & Genel Toplam & 275 & $\mathbf{1 0 0 . 0 0 \%}$ & 275 & $100.00 \%$ \\
\hline
\end{tabular}

Tablo 7'de işlem sayısına göre hem hedef hem de alıcı şirketlerin ana faaliyet alanları ile bilgiler yer almaktadır. Toplam 275 işlem sayısına göre, yurt dışına yatırım yapan Türk şirketlerinin faaliyet gösterdikleri sektörlere baktığımızda $\% 33$ oranında finans ve $\% 33$ oranında imalat sektörlerinin önde geldiği görülmektedir. Bunu \%15 oranındaki payıyla ulaşım sektörü takip etmektedir. Buna karşın, hedef şirketlerin faaliyet gösterdikleri endüstriyel alana bakıldığında en yüksek oran \%37 ile imalat sektörüdür. Bunu \%17 ile finans ve \%17 ulaşım sektörü gelmektedir. 
Tablo 8. En Fazla Yatırım Yapılan Alt Sektörler

\begin{tabular}{|c|c|c|c|c|c|c|c|}
\hline \multicolumn{5}{|c|}{ Hedef Şirket } & \multicolumn{4}{c|}{ Alııı Şirket } \\
\hline $\begin{array}{c}\text { SIC } \\
\text { Kodları }\end{array}$ & Sektör & $\begin{array}{c}\text { İşlem } \\
\text { Sayısı }\end{array}$ & Yüzde & $\begin{array}{c}\text { SIC } \\
\text { Kodlar }\end{array}$ & Sektör & $\begin{array}{c}\text { İşlem } \\
\text { Sayısı }\end{array}$ & Yüzde \\
\hline 6021 & Bankacılık & 27 & $9.82 \%$ & 6021 & Bankacılık & 23 & $8.36 \%$ \\
\hline 7374 & $\begin{array}{c}\text { Bilgisayar işleme ve veri } \\
\text { hazırlama }\end{array}$ & 9 & $3.27 \%$ & 6719 & Holdingler & 23 & $8.36 \%$ \\
\hline 4581 & $\begin{array}{c}\text { Havaalanları, uçuş alanları ve } \\
\text { havaalanı terminal hizmetleri }\end{array}$ & 7 & $2.55 \%$ & 6733 & Yatırım ortaklı̆̆ı & 21 & $7.64 \%$ \\
\hline 4731 & Yük taşıma ve kargo & 6 & $2.18 \%$ & & Belirtilmemiş & 15 & $5.45 \%$ \\
\hline 4899 & Iletişim hizmetleri & 6 & $2.18 \%$ & 6799 & Diğer yatırımcılar & 11 & $4.00 \%$ \\
\hline 1081 & Metal madenciliği hizmetleri & 6 & $2.18 \%$ & 4899 & Illetişim hizmetleri & 9 & $3.27 \%$ \\
\hline 1311 & Ham petrol ve doğal gaz & 5 & $1.82 \%$ & 4581 & $\begin{array}{l}\text { Havaalanları, uçuş alanları ve } \\
\text { havalanı terminal hizmetleri }\end{array}$ & 6 & $2.18 \%$ \\
\hline 6719 & Holdingler & 5 & $1.82 \%$ & 3634 & Elektrikli ev eşyaları ve fanlar & 6 & $2.18 \%$ \\
\hline 4725 & Tur operatörleri & 5 & $1.82 \%$ & 4499 & Su taşıma hizmetleri & 6 & $2.18 \%$ \\
\hline 4499 & Su taşıma hizmetleri & 5 & $1.82 \%$ & 2823 & Selülozik suni elyaflar & 5 & $1.82 \%$ \\
\hline & Diğerleri & 194 & $70.55 \%$ & & Diğerleri & 125 & $45.45 \%$ \\
\hline & Genel Toplam & $\mathbf{2 7 5}$ & $\mathbf{1 0 0 . 0 0 \%}$ & & Genel Toplam & $\mathbf{2 7 5}$ & $\mathbf{1 0 0 . 0 0 \%}$ \\
\hline
\end{tabular}

Tablo 8'de ise SIC kodlarının 4 hanesi kullanılarak en fazla yatırım yapılan 10 alt sektör belirlenmiştir. Buna göre alıcı şirketlere bakıldığında, 20 yıllık dönem içerisinde 275 alıcı şirketlerin toplam 46 tanesi (\%16), sırasıyla her birinde 23 işlemin gerçekleştirildiği ticari bankaları $(\% 8)$ ve holding firmaları (\%8) temsil etmektedir. Buna karşın yatıım ortaklıkları tarafından toplamda 21 (\%7) satın alma yapılmıştır. Hedef şirket sektörleri açısından, son yılların gözde sektörlerinden biri olan bilgisayar işleme ve veri hazırlama sektöründe toplam 9 satın alma (\%3) gerçekleşmiştir. Fakat bankalar (27 tane işlem, \%9) hala yatırım yapılan en popüler alan olarak karşımıza çıkmaktadır. Havaalanı ve havaalanı hizmetleri alanı ise en fazla yatırım yapılan üçüncü sektör olarak kabul edilebilir (7 tane işlem, \%2.5).

Grafik 6. Yatay ve Yatay Olmayan Satın Alma Sayısının Yıl Bazında Dağılımı

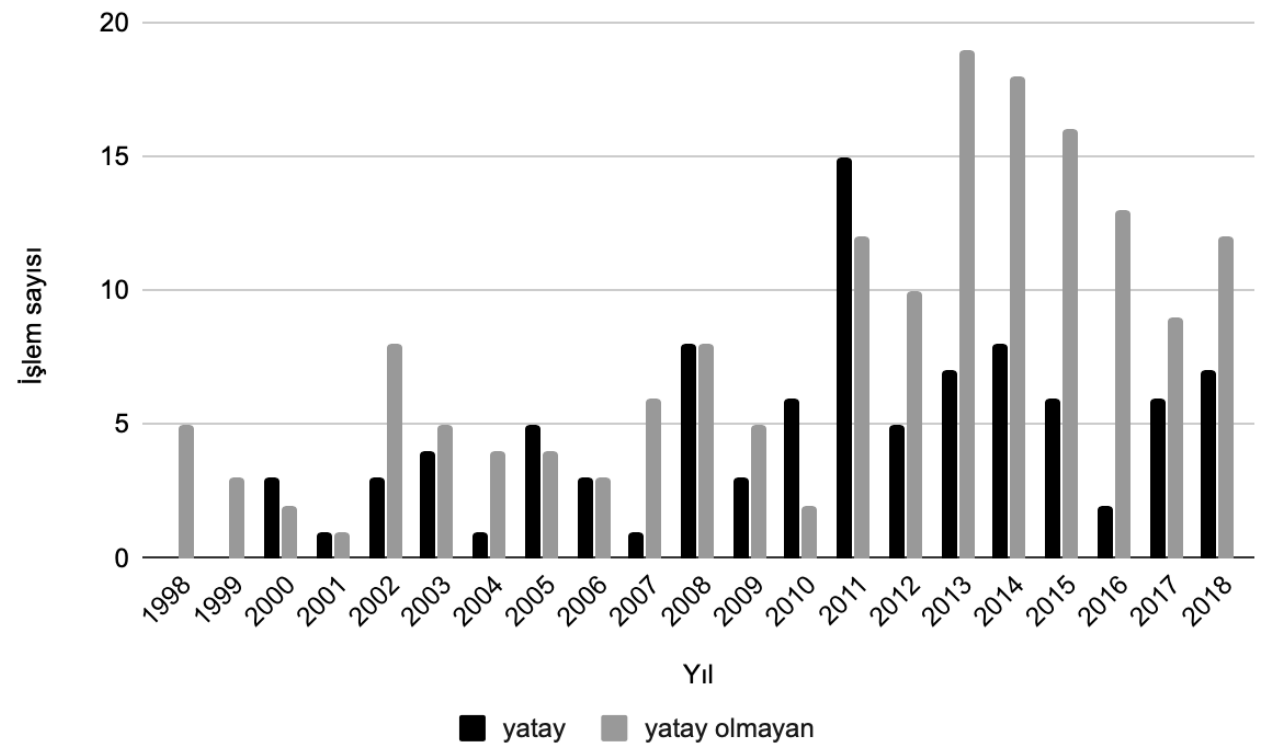


Grafik 6'da, yatay satın alma işlemi aynı sektörde faaliyet gösteren firmalar arası gerçekleşen satın alma işlemini gösterirken, yatay olmayan satın alma işlemi ise farklı sektörler arası gerçekleşen satın alma faaliyetleri anlamına gelmektedir. Bu sınıflandırma 4 haneli SIC kodlarına göre yapılmıştır. Genel olarak grafiğe bakıldığında, tüm yıllar açısından yatay olmayan satın alma faaliyetlerinin (165 işlem), yatay satın almalardan (94 işlem) sayıca fazladır. 16 işlemin sektörel bilgisi verilmediği için bu tabloda bilgisi açıklanmayan işlemlere yer verilmemiştir. En fazla yatay satın almanın yapıldığ y yl 2011 (15 işlem) iken, yatay olmayan satın almanın en fazla yapıldığı yıl 19 işlem sayısı ile 2013 yılıdır. Bunu 2014 yılında yapılan 18 yatay olmayan satın alma faaliyeti takip etmektedir. Sayı olarak yatay satın almanın en fazla gerçekleştiği diğer yıllar ise sırasıyla 2008 (8 işlem) ve 2014 (8 işlem) yıllarıdır. Sadece 2000, 2005, 2010 ve 2011 yıllarında yatay satın almalar, sayıca yatay olmayanlardan fazladır.

\section{SONUÇ VE TARTIŞMA}

Son on yılda uluslararasılaşmak için, özellikle Çin ve Hindistan gibi gelişmekte olan ekonomilerdeki firmaların artan sayıda sınır ötesi birleşmeleri ve satın alma işlemi gerçekleştirdiği görülmüştür (Athreye ve Kapur, 2009:209; Aulakh vd., 2000:342; Gubbi vd., 2010:397). Say1 olarak Çin ve Hindistan kadar olmasa da Türk firmalar tarafından gerçekleştirilen sınır ötesi işlemler de hem iş dünyası hem de akademik dünyanın ilgisini çekmektedir. Bu çalışmada ise spesifik olarak Türkiye'nin taraf olduğu 20 yıllık dönem içerisindeki sınır ötesi satın alma faaliyetleri incelenmiştir. Buna göre, toplam sayıya bakıldığında yabancı yatırımcının Türkiye'de yaptığı satın alma sayısı (883), Türk şirketlerin yurt dışına yaptıkları yatırım sayısından (275) fazladır. Aynı şekilde satın alma işlem değeri, Türk yatırımcı şirketler ile karşılaştırıldığında yabancı yatırımcı açısından hep daha fazladır. Finans ve imalat sektörleri yatırım için en fazla tercih edilen sektörler olarak dikkat çekmektedir. Türk bir firma ile satın alma gerçekleştiren ülkelerin dağılımına bakıldığında, ABD, Almanya, İngiltere, Hollanda ve Fransa ilk beşte yer almaktadır. Türkiye'yi en fazla tercih eden ülke Amerika Birleşik Devletleri iken, Türk şirketleri yatırım için en fazla Romanya'yı tercih etmiştir.

Türkiye'deki yıllar itibariyle artan sınır ötesi satın alma sayısı, Temmuz 2016'dan bu yana Türkiye'de yaşanan olumsuz olaylar nedeniyle azalmıştır. Türkiye ekonomisi ve doğrudan yabancı yatırımlar bu durumdan olumsuz etkilenmiştir. Önde gelen derecelendirme kuruluşları Türkiye'nin hem uluslararası borçlanmayı hem de ülkedeki yabanc1 yatırımı caydırıcı nitelikte olan kredi notunu düşürmüştür (Dünya Yatırım Raporu, 2018:48). Bundan dolayı, sınır ötesi satın alma gibi doğrudan yabancı yatırımcı girişleri, 2016'daki önemli düşüşün ardından 2017 yılında da gerilemeye devam etmiştir. Sonuç olarak 2016 yılından yaşanan ekonomik olumsuzluklar hem say1 olarak hem de işlem hacmi olarak sınır ötesi yatırımların azalmasının nedeni olarak gösterilebilir. Genel olarak bakıldığında ise, kriz dönemlerinde sınır ötesi satın alma işlem sayısının azaldığı görülse de genel olarak artan bir eğilimin söz konusu olduğu söylenebilir.

\section{KAYNAKÇA}

ALHANHANAH, Waleed M., AKBALIK, Murat ve AKOSILE, Abisola Leah (2019), "Merger and Acquisition Patterns and Trends: An Evidence of an Emerging Economy, Turkey", Open Access Library Journal, S.6, ss.1-13.

ANGWIN, Duncan ve SAVILL, Brett (1997), "Strategic Perspectives on European Cross-Border Acquisitions: A View From Top European Executives”, European Management Journal, S.15(4), ss.423-435.

ATHREYE, Suma ve KAPUR, Sandeep (2009), "Introduction: The Internationalization of Chinese and Indian Firms-Trends, Motivations and Strategy", Industrial and Corporate Change, S.18(2), ss.209-221.

AULAKH, Preet, KOTABE, Masaaki ve TEEGEN, Hildy (2000), "Export Strategies and Performance of Firms From Emerging Economies: Evidence From Brazil, Chile, and Mexico", Academy of Management Journal, S.43(3), ss.342-361.

BHAGAT, Sanjai, MALHOTRA, Shavin ve ZHU, Peng Cheng (2011), "Emerging Country Cross-Border Acquisitions: Characteristics, Acquirer Returns and Cross-Sectional Determinants", Emerging Markets Review, S.12(3), ss.250-271.

CAMPLING, John ve MICHELSON, Grant (1998), “A Strategic Choice-Resource Dependence Analysis of Union Mergers in The British and Australian Broadcasting and Film Industries", Journal of Management Studies, S.35(5), ss.579-600. 
AYAS, Sibel - Sınır Ötesi Şirket Satın Alma İşlemlerine Genel Bakış: 1998 - 2018 Dönemi Türk Şirketleri Üzerine Bir İnceleme

CARTWRIGHT, Susan ve COOPER, Cary (1993), "The Role of Culture Compatibility in Successful Organizational Marriage", The Academy of Management Executive, S.7(2), ss.57-70.

CHILD, John, FAULKNER, David ve PITKETHLY, Robert (2001), The Management of International Acquisitions, Oxford University Press, Oxford.

DÜNYA YATIRIM RAPORU (2016), Investor Nationality: Policy Challenges, United Nations Publisher, Geneve, https://unctad.org/en/PublicationsLibrary/wir2016_en.pdf (Erişim Tarihi: 20.05.2020).

DÜNYA YATIRIM RAPORU (2017), Investment and the Digital Economy, United Nations Publisher, Geneve, https://unctad.org/en/PublicationsLibrary/wir2017_en.pdf (Erişim Tarihi: 20.05.2020).

DÜNYA YATIRIM RAPORU (2018), Investment and New Industrial Policies, United Nations Publisher, Geneve, https://unctad.org/en/PublicationsLibrary/wir2018_en.pdf (Erişim Tarihi: 25.05.2020).

DÜNYA YATIRIM RAPORU (2019), Special Economic Zones, United Nations Publisher, Geneve, https://unctad.org/en/PublicationsLibrary/wir2019_en.pdf (Erişim Tarihi: 25.05.2020).

FINKELSTEIN, Sydney (1997), "Interindustry Merger Patterns and Resource Dependence: A Replication and Extension of Pfeffer (1972)", Strategic Management Journal, S.18(10), ss.787-810.

GAUGHAN, Patrick A. (2015), Mergers, Acquisitions and Corporate Restructurings, John Wiley \& Sons Publisher, USA.

GENÇ, Ömer Faruk ve KALKAN, Bilal (2018), "Turkish Mergers and Acquisitions (M\&As): A Historical View of Characteristics, Trends and Directions", Uluslararası Yönetim İktisat ve İşletme Dergisi, S.14(3), ss.791-805.

GUBBI, Sathyajit, AULAKH, Preet, RAY, Sougata, SARKAR, M. B. ve CHITTOOR, Raveendra (2010), “Do International Acquisitions By Emerging-Economy Firms Create Shareholder Value? The Case of Indian Firms", Journal of International Business Studies, S.41(3), ss.397-418.

HEELEY, Michael, KING, David ve COVIN, Jeffrey (2006), "Effects of Firm R\&D Investment and Eenvironment on Acquisition Likelihood", Journal of Management Studies, S.43(7), ss.1513-1535.

HITT, Michael (2000), "The New Frontier: Transformation of Management For The New Millennium", Organizational Dynamics, S.28, ss.6-17.

HITT, Michael, HARRISON, Jeffrey ve IRELAND, R. Duane (2001), Mergers and Acquisitions: A Guide to Creating Value for Stakeholders, Oxford University Press, New York.

HITT, Michael, HARRISON, Jeffrey, IRELAND, R. Duane ve BEST, Aleta (1998), "Attributes of Successful and Unsuccessful Acquisitions of U.S. Firms", British Journal of Management, S.9, ss.91-114.

HITT, Michael ve TYLER, Beverly (1991), "Strategic Decision Models: Integrating Different Perspectives", Strategic Management Journal, S.12(5), ss.327-351.

HOFSTEDE, Geert (1980), Culture's Consequences: International Differences in Work Related Values, Sage, Beverly Hills - CA.

HOUSE, Robert, JAVIDAN, Mansour, HANGES, Paul ve DORFMAN, Peter (2002), “Understanding Cultures and Implicit Leadership Theories Across The Globe: An Introduction To Project GLOBE", Journal of World Business, S.37(1), ss.3-10.

LU, Jane ve BEAMISH, Paul (2004), "International Diversification and Firm Performance: The S-curve Hypothesis", Academy of Management Journal, S.47(4), ss.598-609.

MARTIN, Xavier, SWAMINATHAN, Anand ve MITCHELL, Will (1998), "Organizational Evolution in The Interorganizational Environment: Incentives and Constraints on International Expansion Strategy", Administrative Science Quarterly, S.43, ss.566-601.

MORRESI, Ottorino ve PEZZI, Alberto (2014), Cross-Border Mergers and Acquisitions: Theory and Empirical Evidence, Palgrave, USA.

PALMER, Donald ve BARBER, Brad (2001), "Challengers, Elites, and Owning Families: A Social Class Theoryo of Corporate Acquisitions in The 1960s", Administrative Science Quarterly, S.46(1), ss.87-120. 
SARIKAMIŞ, Cevat (2003), Satın Almalar ve Yeniden Yapılanma Şirket Birleşmeleri, Avcıol Basım Yayım, İstanbul.

SHIMIZU, Katsuhiko, HITT, Michael, VAIDYANATH, Deepa ve PISANO, Vincenzo (2004), "Theoretical Foundations of Cross-Border Mergers and Acquisitions: A Review of Current Research and Recommendations For The Future", Journal of International Management, S.10(3), ss.307-353.

YILDIRIM, Canan (2017), “Turkey's Outward Foreign Direct Investment: Trends and Patterns of Mergers and Acquisitions", Journal of Balkan and Near Eastern Studies, S.19(3), ss.276-293.

EK 1. Yatırım Yapılan Hedef ve Alıcı Ülkelerin Ayrıntıı Listesi

\begin{tabular}{|c|c|c|c|}
\hline Hedef ülke & İşlem Sayısı & Alıcı ülke & İşlem Sayısı \\
\hline Romanya & 24 & Amerika Birleşik Devletleri & 120 \\
\hline Almanya & 22 & Birleşik Krallık & 95 \\
\hline Birleşik Krallık & 21 & Almanya & 84 \\
\hline Bulgaristan & 20 & Hollanda & 78 \\
\hline Hollanda & 17 & Fransa & 61 \\
\hline İtalya & 16 & Avusturya & 32 \\
\hline Amerika Birleşik Devletleri & 16 & İtalya & 27 \\
\hline Rusya Federasyonu & 13 & Lüksemburg & 25 \\
\hline Fransa & 8 & Yunanistan & 24 \\
\hline Ukrayna & 8 & Cayman Adaları & 22 \\
\hline Kanada & 7 & İspanya & 22 \\
\hline Makedonya (Fyrom) & 6 & İsveç & 22 \\
\hline Arnavutluk & 5 & Birleşik Arap Emirlikleri & 22 \\
\hline Macaristan & 5 & İsviçre & 20 \\
\hline Sirbistan & 5 & Japonya & 19 \\
\hline Avusturya & 4 & Belçika & 18 \\
\hline Azerbaycan & 4 & Kuveyt & 14 \\
\hline Hirvatistan & 4 & Katar & 14 \\
\hline Polonya & 4 & Polonya & 12 \\
\hline İspanya & 4 & Rusya Federasyonu & 12 \\
\hline İsviçre & 4 & Azerbaycan & 11 \\
\hline Özbekistan & 4 & Suudi Arabistan & 10 \\
\hline Belçika & 3 & Panama & 8 \\
\hline Bosna Hersek & 3 & Danimarka & 7 \\
\hline Çek Cumhuriyeti & 3 & Norveç & 7 \\
\hline Gürcistan & 3 & Kanada & 6 \\
\hline Kazakistan & 3 & Çin & 5 \\
\hline
\end{tabular}


AYAS, Sibel - Sınır Ötesi Şirket Satın Alma İşlemlerine Genel Bakış: 1998 - 2018 Dönemi Türk Şirketleri Üzerine Bir İnceleme

\begin{tabular}{|c|c|c|c|}
\hline Karadağ & 3 & Finlandiya & 5 \\
\hline İsveç & 3 & İsrail & 5 \\
\hline Kıbris & 2 & Singapur & 5 \\
\hline Misir & 2 & Güney Afrika & 5 \\
\hline Hindistan & 2 & Belirtilmemiş & 5 \\
\hline İsrail & 2 & Bahreyn & 4 \\
\hline Kosova & 2 & Hindistan & 4 \\
\hline Suudi Arabistan & 2 & İrlanda & 4 \\
\hline Cezayir & 1 & Malezya & 4 \\
\hline Arjantin & 1 & Portekiz & 4 \\
\hline Avustralya & 1 & Bulgaristan & 3 \\
\hline Belarus & 1 & Çek Cumhuriyeti & 3 \\
\hline Brezilya & 1 & Misir & 3 \\
\hline Burkina Faso & 1 & Hong Kong & 3 \\
\hline Çin & 1 & İzlanda & 3 \\
\hline Danimarka & 1 & Avustralya & 2 \\
\hline Etiyopya & 1 & Bermuda & 2 \\
\hline Finlandiya & 1 & Brezilya & 2 \\
\hline Yunanistan & 1 & Meksika & 2 \\
\hline Hong Kong & 1 & Kore Cumhuriyeti & 2 \\
\hline Endonezya & 1 & Romanya & 2 \\
\hline Irak & 1 & Tunus & 2 \\
\hline Ürdün & 1 & Bahamalar & 1 \\
\hline Letonya & 1 & Brunei Sultanlığ & 1 \\
\hline Lüksemburg & 1 & Curacao & 1 \\
\hline Portekiz & 1 & Haiti & 1 \\
\hline Katar & 1 & Ürdün & 1 \\
\hline Güney Afrika & 1 & Kazakistan & 1 \\
\hline Türkmenistan & 1 & Lübnan & 1 \\
\hline \multirow[t]{6}{*}{ Genel Toplam } & 275 & Malta & 1 \\
\hline & & Umman & 1 \\
\hline & & Papua Yeni Gine & 1 \\
\hline & & Tayland & 1 \\
\hline & & Virgin Adaları & 1 \\
\hline & & Genel Toplam & 883 \\
\hline
\end{tabular}

